Paper ini merupakan versi preprint dari makalah berjudul "Groundwater flooding due to Tropical Cyclone Cempaka in Ngreneng Karst Window, Gunungsewu Karst Area, Indonesia”. Versi Bahasa Inggris dari paper ini kami presentasikan di "Joint International Conference on Hydro-Meteorological Disaster Mitigation Under Global Change" tanggal 29 November 2018 di Universitas Gadjah Mada Yogyakarta. Seminar ini diselenggarakan oleh Kementerian Lingkungan Hidup dan Kehutanan RI dan Klinik Lingkungan dan Mitigasi Bencana, Fakultas Geografi, Universitas Gadjah Mada

\title{
Banjir Airtanah Akibat Siklon Tropis Cempaka di Karst Window Ngreneng, Kawasan Karst Gunungsewu, Indonesia
}

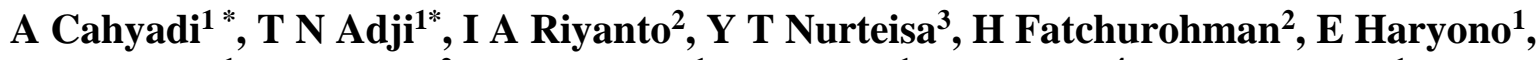 \\ H Reinhard ${ }^{1}$, R F Agniy ${ }^{2}$, A Nurkholis', M Naufal' ${ }^{1}$, E Nurjani', M Widyastuti ${ }^{1}$ \\ ${ }^{1}$ Karst Research Group, Faculty of Geography, Universitas Gadjah Mada, Indonesia \\ *ahmadcahyadi@geo.ugm.ac.id, *adji@geo.ugm.ac.id \\ ${ }^{2}$ Lentera Geosains, Yogyakarta, Indonesia \\ ${ }^{3} \mathrm{CV}$ Mitra Geotama, Yogyakarta, Indonesia \\ ${ }^{4}$ Department of Environmental Geography, Faculty of Geography, Universitas Gadjah Mada, Indonesia
}

\begin{abstract}
Tropical Cyclone Cempaka occurred on November 27, 2017 in the Indian Ocean, just south of Central Java. This incident induced high rainfall leading to flash floods in the southern part of Central Java, including Gunungsewu Karst Area. The highest rainfall recorded on November 28, 2017, in this area was $239 \mathrm{~mm}$ /day (Automatic Rainfall Recorder/ARR Station in Pindul Cave) and $341 \mathrm{~mm} /$ day (ARR Station in Tepus). The extreme rainfall also caused groundwater flood in Ngreneng Karst Window. This study aimed to analyze the mechanism of this flood. The results of the analysis showed that it was caused by water filling up the conduit passage in the entire Bribin-Baron underground river system. The flow of the conduit pushed the diffuse flow into the surface fast, and the water that came out of Ngreneng Karst Window was thereby clear. The inundation lasted for ten days and submerged up to 26.4 ha of the study area.
\end{abstract}

Keywords: Tropical Cyclone Cempaka, Groundwater Flooding, Ngreneng Karst Window, Gunungsewu Karst Area

\section{INTRODUCTION}

Terjadinya Siklon Tropis Cempaka di Samudra Hindia tepat di Selatan Pualau Jawa pada akhir Bulan November sampai dengan Awal Desember lalu meninggalkan dampak bencana sekaligus pelajaran yang berharga bagi pengembangan ilmu hidrologi karst dan menajemen kebencanaan. Wilayah-wilayah yang jarang mengalami bencana banjir atau bahkan lebih sering dikenal sebagai wilayah yang mengalami bencana kekeringan ternyata mengalami banjir dengan karakter yang unik dari sisi ilmu hidrologi ataupun geomorfologi. Kejadian banjir yang terjadi di lokasi yang sangat jarang mengalami banjir ternyata menyebabkan dampak sangat besar karena 
Paper ini merupakan versi preprint dari makalah berjudul "Groundwater flooding due to Tropical Cyclone Cempaka in Ngreneng Karst Window, Gunungsewu Karst Area, Indonesia”. Versi Bahasa Inggris dari paper ini kami presentasikan di "Joint International Conference on Hydro-Meteorological Disaster Mitigation Under Global Change" tanggal 29 November 2018 di Universitas Gadjah Mada Yogyakarta. Seminar ini diselenggarakan oleh Kementerian Lingkungan Hidup dan Kehutanan RI dan Klinik Lingkungan dan Mitigasi Bencana, Fakultas Geografi, Universitas Gadjah Mada

masyarakat tidak siap. Kondisi tersebut karena masyarakat tidak memiliki pengalaman dan bahkan tidak menyangka akan dilanda bencana banjir di lokasi yang sekian lama mereka tempati.

Siklon Tropis Cempaka mulai diidentifikasi muncul oleh Badan Metorologi, Klimatologi dan Geofisika Indonesia pada tanggal 27 November 2017 pukul 19.00 WIB. Posisi awal siklon ini berada di sekitar $100 \mathrm{~km}$ sebelah tenggara Kota Cilacap, Provinsi Jawa Tengah. Badai ini bergerak dengan kecepatan sekitar $65 \mathrm{~km} / \mathrm{jam}$, dan menyebabkan berbagai bencana seperti tanah longsor, banjir, pohon tumbang dan angin ribut.

Siklon Tropis Cempaka menyebabkan terjadinya kerusakan rumah, fasilitas ibadah, perkantoran, fasilitas kesehatan, dan pendidikan. Jumlah kerusakan rumah di Daerah Istimewa Yogyakarta yang terdampak Siklon Tropis Cempaka adalah sejumlah 122 rumah dengan rincian 86 rumah rusak ringan, 21 rumah rusak sedang dan 15 rumah rusak berat. Selain itu, Siklon Tropis Cempaka menyebabkan terjadinya korban jiwa sejumlah 19 orang baik di Daerah Istimewa Yogyakarta, Provinsi Jawa Tengah (Kabupaten Wonogiri 2 orang dan Kabupaten Wonosobo 1 orang) dan Provinsi Jawa Timur (Kabupaten Pacitan, 11 orang). Dampak Siklon Tropis Cempaka di Daerah Istimewa Yogyakarta secara lengkap disajikan pada Tabel 1.

Tabel 1. Dampak Siklon Tropis Cempaka di Daerah Istimewa Yogyakarta

\begin{tabular}{|c|c|c|c|c|}
\hline Kabupaten/Kota & $\begin{array}{c}\text { Pohon } \\
\text { Tumbang }\end{array}$ & Banjir & Longsor & Korban Jiwa \\
\hline Yogyakarta & 1 lokasi & 14 lokasi & 10 lokasi & 3 \\
\hline Kulonprogo & 6 lokasi & 61 lokasi & 28 lokasi & 1 \\
\hline Gunungkidul & 44 lokasi & 51 lokasi & 26 lokasi & 1 \\
\hline Bantul & 57 lokasi & 46 lokasi & 76 lokasi & 0 \\
\hline Sleman & 27 lokasi & 20 lokasi & 26 lokasi & 5 \\
\hline Jumlah & 135 lokasi & 151 lokasi & 146 lokasi & 0 \\
\hline
\end{tabular}

Sumber: Pusat Pengendali Operasi (Pusdalops) Badan Penanggulangan Bencana Daerah (BPBD) DIY, BPBD Kabupaten Gunungkidul dan Survei Lapangan 
Paper ini merupakan versi preprint dari makalah berjudul "Groundwater flooding due to Tropical Cyclone Cempaka in Ngreneng Karst Window, Gunungsewu Karst Area, Indonesia”. Versi Bahasa Inggris dari paper ini kami presentasikan di "Joint International Conference on Hydro-Meteorological Disaster Mitigation Under Global Change" tanggal 29 November 2018 di Universitas Gadjah Mada Yogyakarta. Seminar ini diselenggarakan oleh Kementerian Lingkungan Hidup dan Kehutanan RI dan Klinik Lingkungan dan Mitigasi Bencana, Fakultas Geografi, Universitas Gadjah Mada

Kawasan Karst Gunungsewu adalah adalah salah satu kawasan karst di Indonesia yang dikenal sebagai wilayah rawan bencana kekeringan (Haryono et.al., 2009; Fatchurohman and Cahyadi, 2011; Cahyadi, 2016). Namun demikian, kejadian Siklon Tropis Cempaka membuka mata kita bahwa wilayah ini juga merupakan wilayah yang memiliki bahaya banjir. Oleh karena itu, dokumentasi terkait dengan kejadian banjir yang terjadi di kawasan Karst Gunungsewu penting untuk didokumentasikan dan dikaji mekanisme terjadinya. Penelitian ini bertujuan untuk menganalisis mekanisme terjadinya banjir airtanah di Karst Window Ngreneng (Gambar 1). Kejadian banjir di lokasi ini tahun 2017 telah menyebabkan keramaian di masyarakat karena terbentuknya danau sementara di sebuah doline.

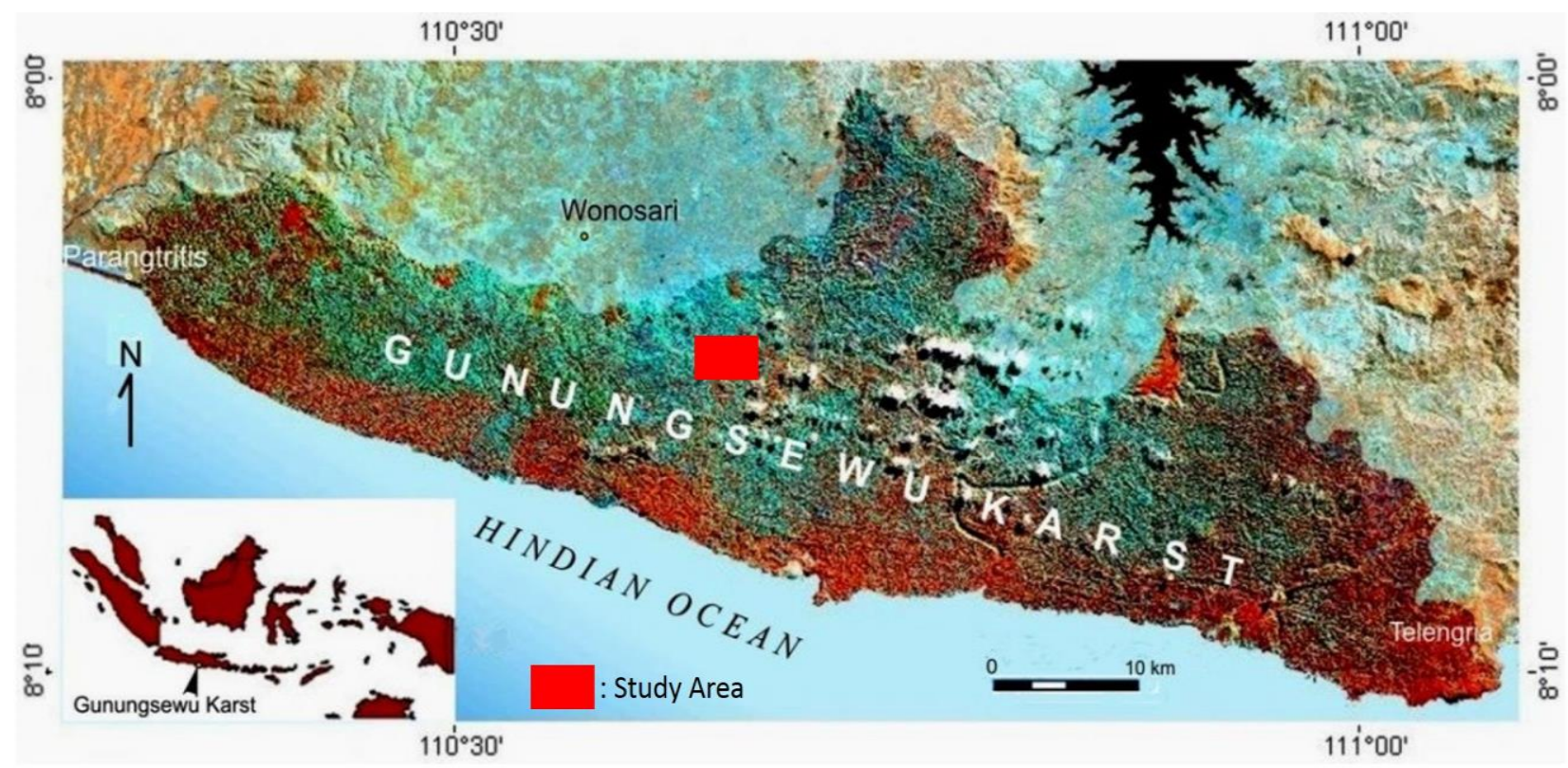

Gambar 1. Peta Lokasi Karst Window Ngreneng di Kawasan Karst Gunungsewu

\section{METHODS}

Bahasan yang terdapat dalam paper ini meliputi karakteristik curah hujan, luas pengenangan, lama penggenangan, daerah tangkapan,kronologi kejadian dan analisis mekanisme terjadinya banjir airtanah di Karst Window Ngreneng. Data hujan yang digunakan adalah data hujan dari stasiun penelitian kelompok studi karst (berupa Automatic Rainfall Recorderl ARR) yang terletak di Gua Pindul, Kecamatan Karangmojo, Kabupaten Gunungkidul, serta Stasiun 
Paper ini merupakan versi preprint dari makalah berjudul "Groundwater flooding due to Tropical Cyclone Cempaka in Ngreneng Karst Window, Gunungsewu Karst Area, Indonesia”. Versi Bahasa Inggris dari paper ini kami presentasikan di "Joint International Conference on Hydro-Meteorological Disaster Mitigation Under Global Change" tanggal 29 November 2018 di Universitas Gadjah Mada Yogyakarta. Seminar ini diselenggarakan oleh Kementerian Lingkungan Hidup dan Kehutanan RI dan Klinik Lingkungan dan Mitigasi Bencana, Fakultas Geografi, Universitas Gadjah Mada

ARR Tepus milik Badan Meteorologi, Klimatologi dan Geofisika (BMKG). Analisis luas genangan dianalisis dari pemotretan lokasi kajian dengan menggunakan pesawat tanpa awak. Kondisi wilayah tangkapan air dianalisis dari hasil penelitian terdahulu di lokasi kajian dan survey lapangan di lapangan. Data lamanya genangan diperoleh dari pengamatan lapangan. Hasil kajian tersebut kemudian disintesiskan untuk memahami mekanisme banjir airtanah yang terjadi di lokasi kajian.

\section{RESULTS AND DISCUSSION}

Hasil analisis data hujan stasiun penelitian ARR Gua Pindul dan ARR Stasiun Tepus menunjukkan bahwa pada tanggal 28 November 2018 telah terjadi hujan sangat lebat (>100 $\mathrm{mm} / \mathrm{hari}$ ) berdasarkan klasifikasi hujan dari BMKG dan hujan ekstrim (>50 mm/hari) berdasarkan klasifikasi dari Badan Nasional Penanggulangan Bencana (BNPB) Republik Indonesia. Curah hujan di stasiun penelitian ARR Gua Pindul mencatat curah hujan di tanggal 28 November 2017 adalah 239 mm/hari, sedangkan curah hujan yang tercatat di ARR stasiun Tepus adalah $341 \mathrm{~mm} /$ hari. Hasil pencatatan yang dilakukan oleh Stasiun Klimatologi Yogyakarta (BMKG) menunjukkan bahwa curah hujan di seluruh Kawasan Karst Gunungsewu tercatat lebih dari $100 \mathrm{~mm} /$ hari, dengan curah hujan tertinggi sebesar $341 \mathrm{~mm} /$ hari. Curah hujan rata-rata bulanan di stasiun Tepus adalah $200 \mathrm{~mm} /$ bulan, dengan puncak pada Bulan Januari dan Desember yang mencapai $400 \mathrm{~mm} /$ bulan (Sudarmadji et.al., 2012). Rata-rata hujan bulanan pada Bulan November adalah $251 \mathrm{~mm} /$ bulan. Hal ini berarti bahwa hujan yang terjadi saat ini sama dengan hujan satu bulan yang terjadi dalam satu hari.

Luas penggenangan maksimum dari kejadian banjir airtanah di Karst Window Ngreneng adalah 26,4 hektar (Gambar 2). Hasil tersebut diperoleh dari pemotretan dengan menggunakan pesawat tanpa awak dan Survei Lapangan (Gambar 3). Genangan meluas mengikuti topografi cekungan tertutup atau doline. Genangan terluas terjadi pada tanggal 29 November 2017. Genangan tersebut kemudian surut pada tanggal 7 Desember 2017 atau 10 hari sejak terjadi genangan. 
Paper ini merupakan versi preprint dari makalah berjudul "Groundwater flooding due to Tropical Cyclone Cempaka in Ngreneng Karst Window, Gunungsewu Karst Area, Indonesia". Versi Bahasa Inggris dari paper ini kami presentasikan di "Joint International Conference on Hydro-Meteorological Disaster Mitigation Under Global Change" tanggal 29 November 2018 di Universitas Gadjah Mada Yogyakarta. Seminar ini diselenggarakan oleh Kementerian Lingkungan Hidup dan Kehutanan RI dan Klinik Lingkungan dan Mitigasi Bencana, Fakultas Geografi, Universitas Gadjah Mada

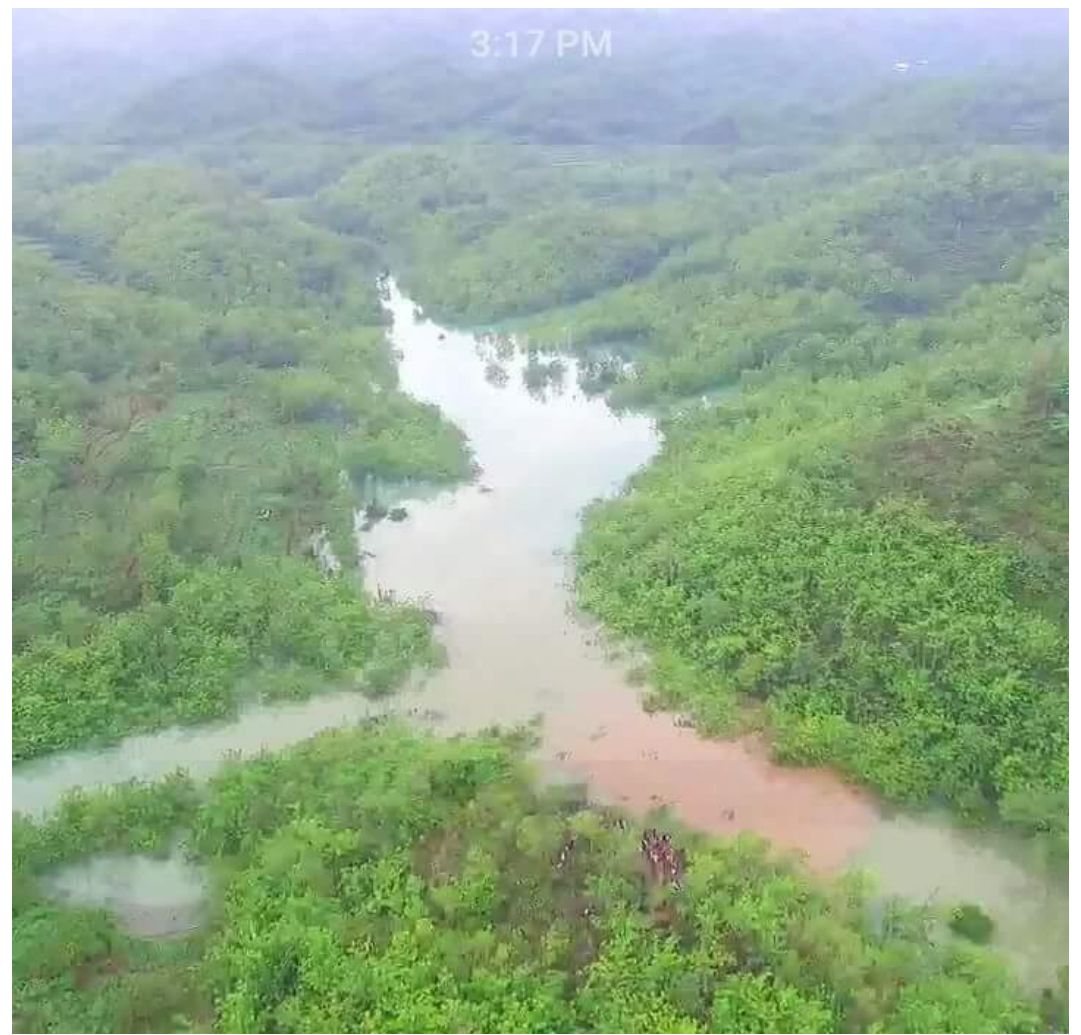

Gambar 2. Hasil Foto Udara Oblique di Lokasi Kajian (Foto oleh Hendy Fatchurohman)

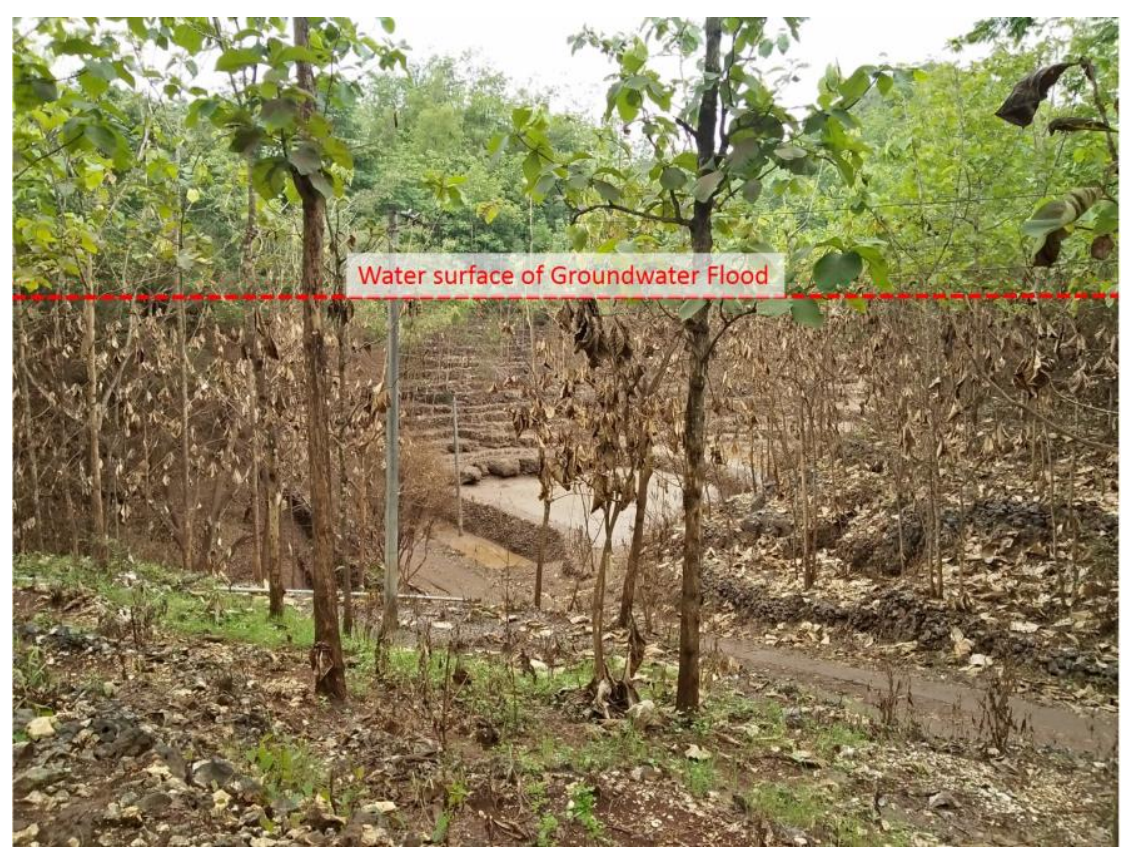

Gambar 3. Jejak banjir airtanah di Karst Window Ngreneng (Foto oleh Ahmad Cahyadi) 
Paper ini merupakan versi preprint dari makalah berjudul "Groundwater flooding due to Tropical Cyclone Cempaka in Ngreneng Karst Window, Gunungsewu Karst Area, Indonesia”. Versi Bahasa Inggris dari paper ini kami presentasikan di "Joint International Conference on Hydro-Meteorological Disaster Mitigation Under Global Change" tanggal 29 November 2018 di Universitas Gadjah Mada Yogyakarta. Seminar ini diselenggarakan oleh Kementerian Lingkungan Hidup dan Kehutanan RI dan Klinik Lingkungan dan Mitigasi Bencana, Fakultas Geografi, Universitas Gadjah Mada

Ditinjau dari sistem hidrogeologi, Karst Window Ngreneng masuk dalam sistem sungai bawah tanah Bribin-Baron, yang merupakan sistem sungai bawah tanah terbesar dan terluas di Kawasan Karst Gunungsewu (Adji, 2011). Penurunan batuan dasar di bawah batuan gamping yang saat ini nampak di permukaan menyebabkan aliran sungai bawah tanah di sistem ini memusat dan keluar sebagai mataair di Pantai Baron (Notosiswoyo and Kusumayudha, 1998; Kusumayudha et.al, 2015). Karst Window Ngreneng merupakan bocoran dari Sungai Bawah Tanah Bribin Adji (2010) (Gambar 4). Aliran air di Gua ini sangat terkait dengan aliran air yang berada di Sungai Bawah Tanah Bribin. Penelitian terbaru menyebutkan bahwa aliran sungai bawah tanah di Karst Window Ngreneng juga dipasok dari Sungai Bawah Tanah Seropan (Sidauruk et.al., 2018).

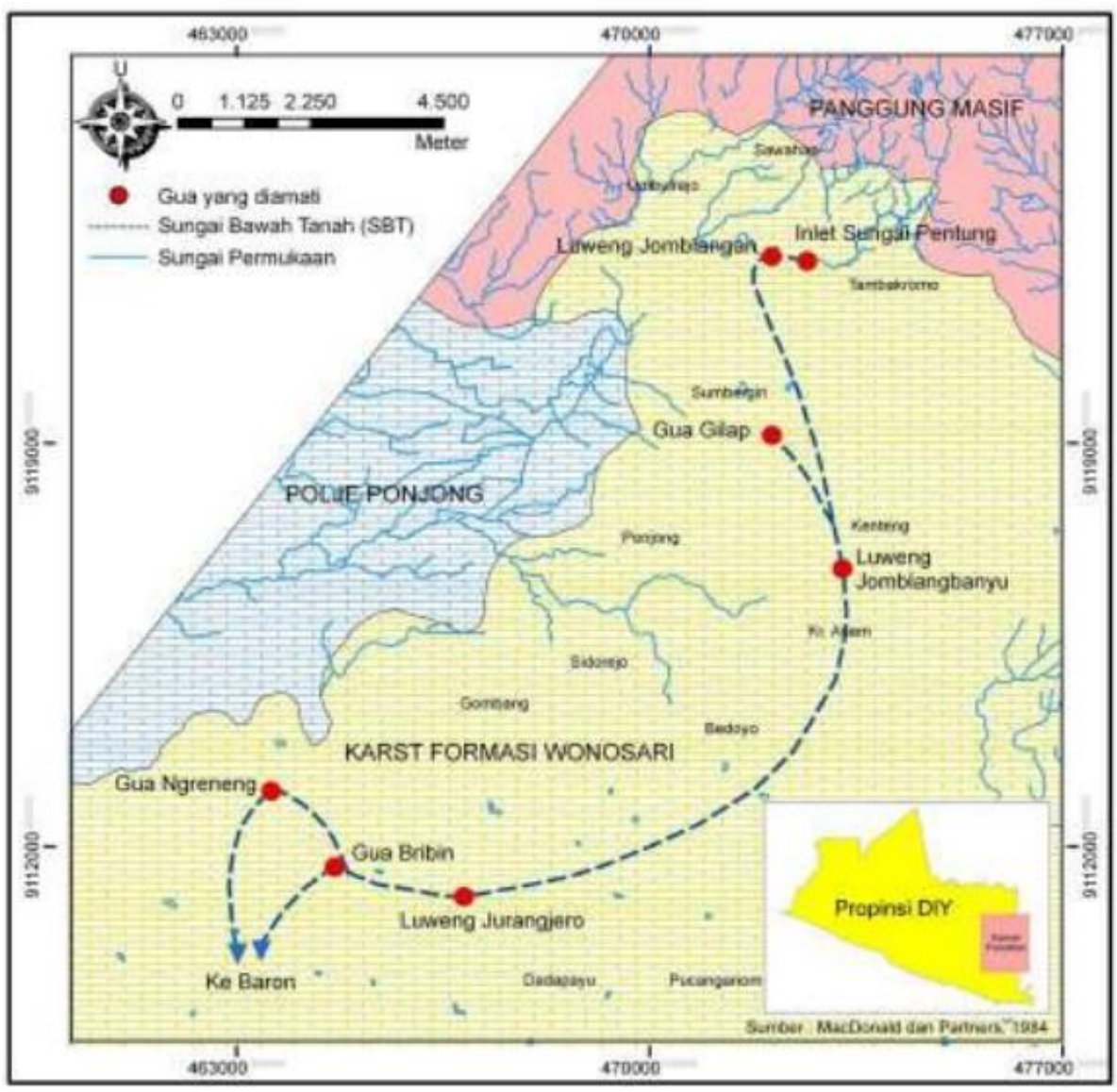

Gambar 4. Gua Ngreneng sebagai Bocoran dan Sungai Bawah Tanah Bribin (Adji, 2010) 
Paper ini merupakan versi preprint dari makalah berjudul "Groundwater flooding due to Tropical Cyclone Cempaka in Ngreneng Karst Window, Gunungsewu Karst Area, Indonesia”. Versi Bahasa Inggris dari paper ini kami presentasikan di "Joint International Conference on Hydro-Meteorological Disaster Mitigation Under Global Change" tanggal 29 November 2018 di Universitas Gadjah Mada Yogyakarta. Seminar ini diselenggarakan oleh Kementerian Lingkungan Hidup dan Kehutanan RI dan Klinik Lingkungan dan Mitigasi Bencana, Fakultas Geografi, Universitas Gadjah Mada

Ditinjau dari kondisi geomorfologi, Gua Ngreneng adalah sebuah "karst window". Karst window (Gambar 5) adalah bentukkan alamiah di kawasan karst yang terbentuk akibat runtuhnya sungai bawah tanah, sehingga sebagian dari sungai bawah tanah terekspos ke permukaan pada dasar lembah karst (doline). Beberapa ahli menyebutnya sebagai estavelle, yakni sebuah istilah yang berasal dari Karst Dinarik yang ada di Eropa. Namun beberapa syarat nyatanya tidak memenuhi untuk disebut sebagai estavelle. Estavelle memiliki karakteristik sebagai mataair intermitten (mengalir pada waktu tertentu) karena perubahan muka airtanah (dominasi aliran diffuse/ aliran antar butir) dan pada waktu tertentu berperan sebagai pengatus (sinkhole) (Milanovic,1981). Hal ini jelas tidak sesuai dengan kondisi di Ngreneng yang memiliki aliran sepanjang tahun dan didominasi oleh aliran sungai bawah tanah (konduit), meskipun Gua Ngreneng juga memiliki peran sebagai pengatus air (sinkhole).

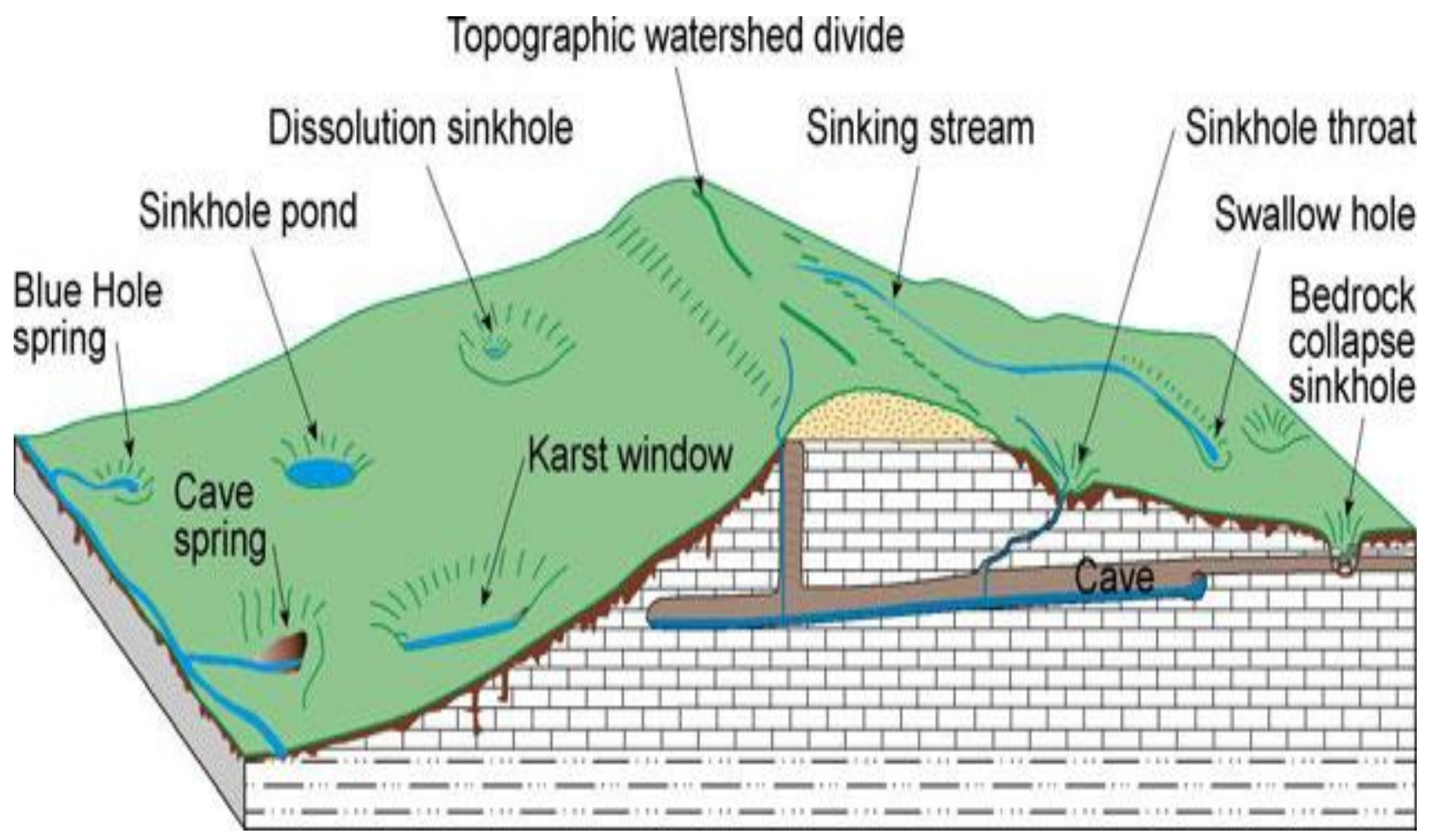

Gambar 5. Skema Garis Besar Bentuklahan di Kawasan Karst (Sumber: https://www.uky.edu/KGS/water/general/karst/blockdiagram.jpg) 
Paper ini merupakan versi preprint dari makalah berjudul "Groundwater flooding due to Tropical Cyclone Cempaka in Ngreneng Karst Window, Gunungsewu Karst Area, Indonesia”. Versi Bahasa Inggris dari paper ini kami presentasikan di "Joint International Conference on Hydro-Meteorological Disaster Mitigation Under Global Change" tanggal 29 November 2018 di Universitas Gadjah Mada Yogyakarta. Seminar ini diselenggarakan oleh Kementerian Lingkungan Hidup dan Kehutanan RI dan Klinik Lingkungan dan Mitigasi Bencana, Fakultas Geografi, Universitas Gadjah Mada

Penyebab utama terjadinya luapan di Gua Ngreneng adalah besarnya volume air yang mengalir di dalam sungai bawah tanah. Aliran tersebut melebihi kapasitas pengaliran dari sungai bawah tanah di Karst Window Ngreneng yang ukurannya kecil (Gambar 6). Besarnya curah hujan yang yang terjadi sebagai dampak Siklon Tropis Cempaka menyebabkan volume air yang harus diatuskan melalui sungai bawah tanah di Sungai Bawah Tanah Bribin menjadi sangat banyak. Hal ini ditunjukkan pula dari pernyataan yang dikeluarkan oleh pengelola bendungan Bribin yang menyebutkan bahwa ketinggian air di bendungan Bribin normalnya 36 meter, namun pada tanggal 28 November 2017 mencapai ketinggian 64 meter. Hal ini mengakibatkan mesin pompa di Sungai Bawah Tanah Bribin II atau Sindon dimatikan. Masukan air yang lebih besar dibandingkan kapasitas penyaluran lorong sungai bawah tanah memungkinkan naiknya air melalui karst window dan air akan surut dengan waktu tertentu. Skema sederhana atas mekanisme ini dapat dilihat dalam Gambar 7.

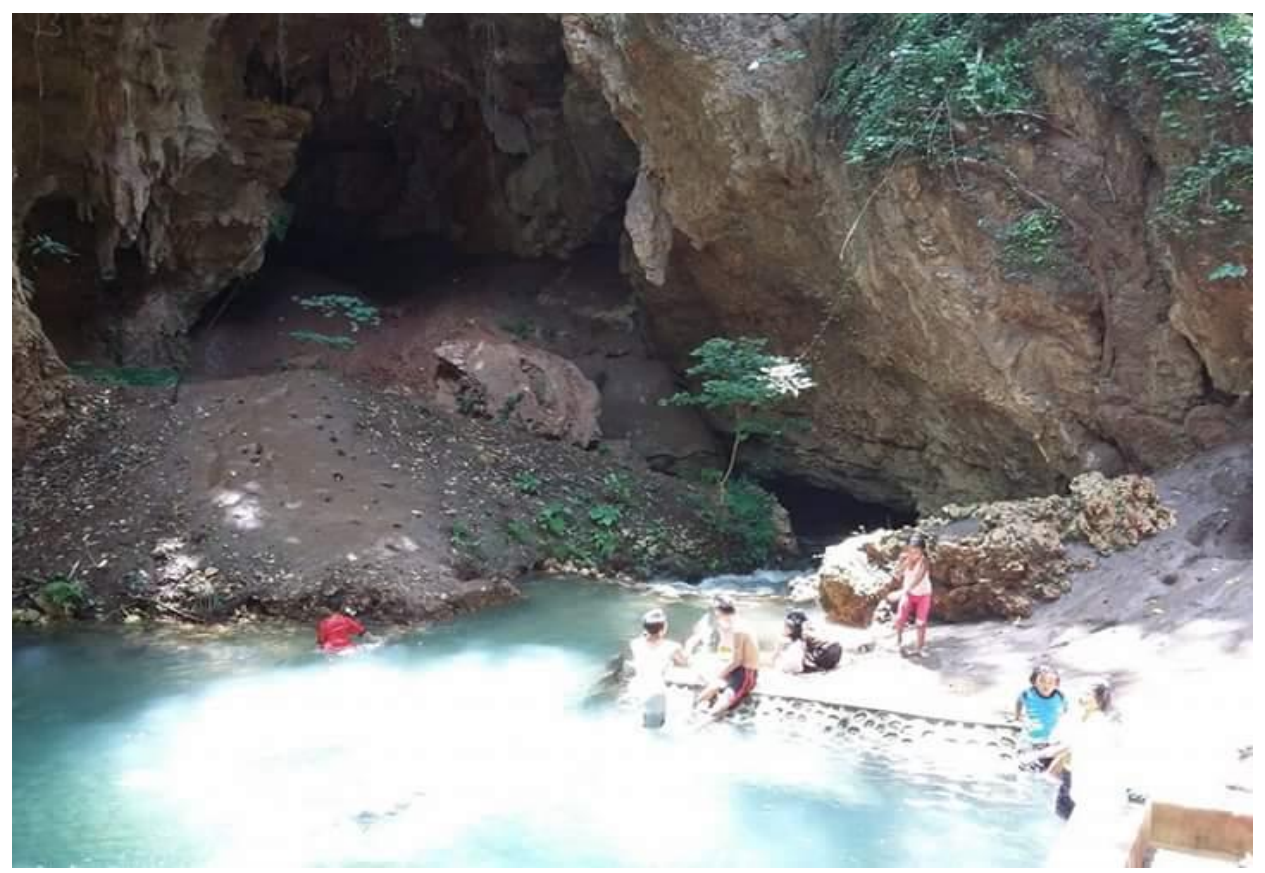

Gambar 6. Lorong Pengatusan Gua Ngreneng yang Kecil

(Foto Tahun 2011 pada Musim Kemarau oleh Ahmad Cahyadi) 
Paper ini merupakan versi preprint dari makalah berjudul "Groundwater flooding due to Tropical Cyclone Cempaka in Ngreneng Karst Window, Gunungsewu Karst Area, Indonesia”. Versi Bahasa Inggris dari paper ini kami presentasikan di "Joint International Conference on Hydro-Meteorological Disaster Mitigation Under Global Change" tanggal 29 November 2018 di Universitas Gadjah Mada Yogyakarta. Seminar ini diselenggarakan oleh Kementerian Lingkungan Hidup dan Kehutanan RI dan Klinik Lingkungan dan Mitigasi Bencana, Fakultas Geografi, Universitas Gadjah Mada

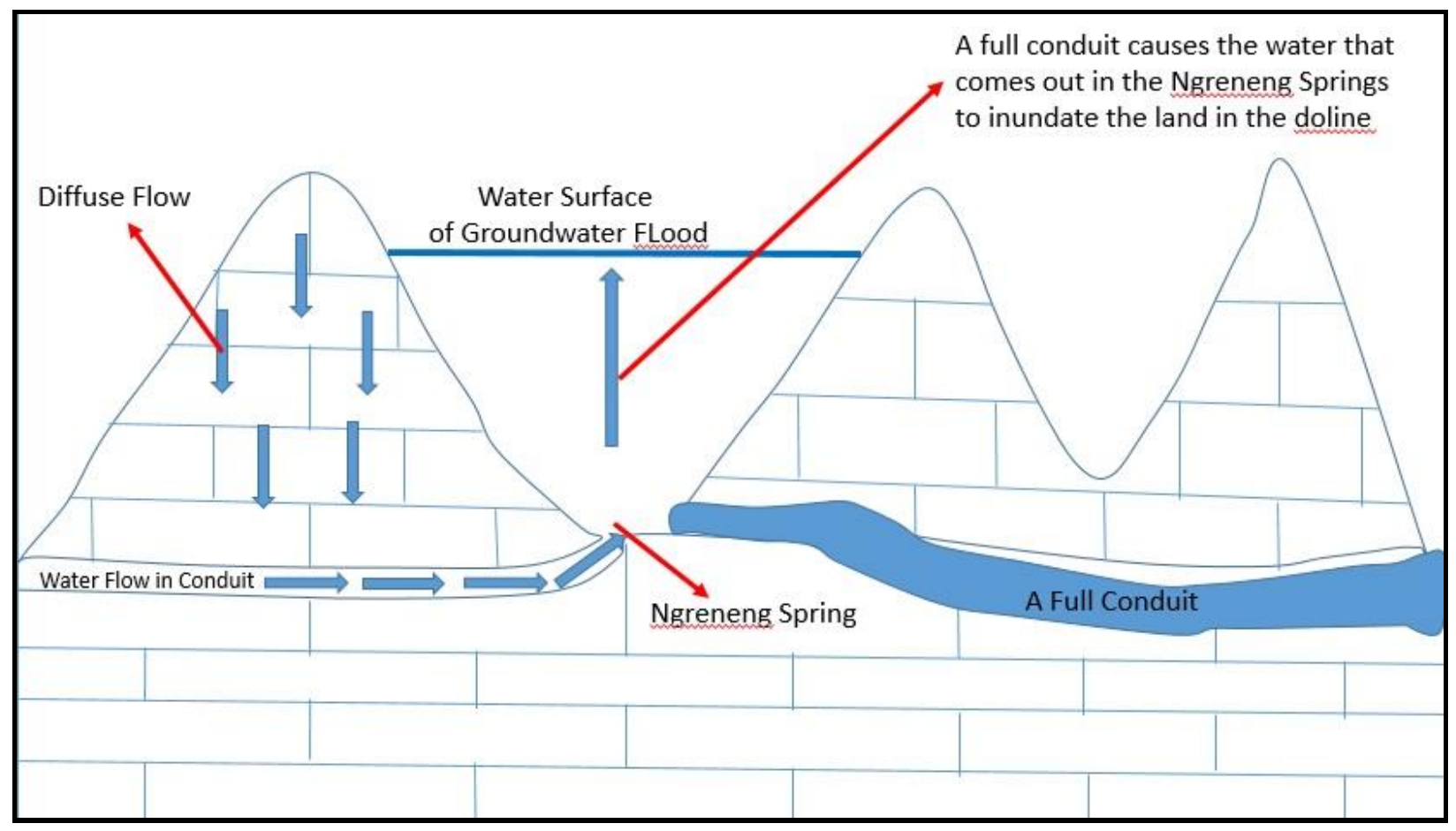

Gambar 7. Mekanisme Penggenangan di Gua Ngreneng

Kondisi yang unik terjadi pada banjir air tanah di Karst Window Ngreneng adalah air yang meluap bersifat jernih atau tidak keruh. Kondisi demikian berbeda dengan penggenangan yang terjadi di Gua Kalisuci dan Gua Sumurup (Gambar 8). Setidaknya ada dua sebab yang dapat menjelaskan peristiwa ini. Pertama, terkait dengan imbuhan utama yang mengalir ke Gua Ngreneng dan kedua, mekanisme pengaliran yang didominasi oleh aliran diffuse.

Dalam hidrologi kawasan karst, imbuhan airtanah atau sungai bawah tanah secara garis besar dibagi menjadi dua, yakni imbuhan allogenic dan imbuhan autogenic. Imbuhan allogenic adalah imbuhan airtanah atau sungai bawah tanah yang asalnya dari kawasan non-karst (White, 1988). Imbuhan ini biasanya masuk melalui sungai permukaan yang kemudian masuk ke dalam sungai bawah tanah sebagai sungai yang menghilang seperti Sinking Stream Kalisuci dan Gua Sumurup (Cahyadi et.al., 2018). Sinking Stream Kalisuci misalnya adalah outlet dari Sungai Jirak yang mengalir dari Kecamatan Ponjong dan sebagian Semanu. Air yang mengalir di 
Paper ini merupakan versi preprint dari makalah berjudul "Groundwater flooding due to Tropical Cyclone Cempaka in Ngreneng Karst Window, Gunungsewu Karst Area, Indonesia". Versi Bahasa Inggris dari paper ini kami presentasikan di "Joint International Conference on Hydro-Meteorological Disaster Mitigation Under Global Change" tanggal 29 November 2018 di Universitas Gadjah Mada Yogyakarta. Seminar ini diselenggarakan oleh Kementerian Lingkungan Hidup dan Kehutanan RI dan Klinik Lingkungan dan Mitigasi Bencana, Fakultas Geografi, Universitas Gadjah Mada

permukaan menyebabkan air menjadi keruh karena bercampur dengan tanah yang tererosi (Widyastuti et.al, 2012). Kondisi berbeda terjadi jika imbuhan air bersifat autogenic, di mana air meresap berasal dari air hujan yang meresap melalui diaklas/ retakan-retakan pada kawasan karst yang kemudian secara gravitatif turun sampai dengan sungai bawah tanah (Haryono, 2000). Proses penyaringan oleh tanah, retakan dan rongga batuan menyebabkan air yang masuk ke sungai bawah tanah menjadi lebih jernih (Adji, 2006). Meskipun Karst Window Ngreneng memiliki sistem autogenic dan allogenic (Cahyadi et.al., 2018), namun kapasitas pelepasan aliran diffusenya ternyata sangat besar (Adji, 2010), sehingga pelepasan diffuse yang jernih menjadi dominan terutama terkait dengan jumlah imbuhan autogenic yang besar pada hari Kamis kemarin. Selain itu, aliran diffuse yang telah lebih dahulu memenuhi lorong sungai bawah tanah saat terjadi banjir terdorong oleh aliran allogenik, sehingga yang naik sebagai genangan di permukaan adalah aliran diffuse. Hal ini nampak dari perubahan warnah yang mulai terjadi setelah 4 hari. Aliran allogenik yang masuk kemudian menyebabkan genangan air di Karst Window Ngreneng menjadi keruh.

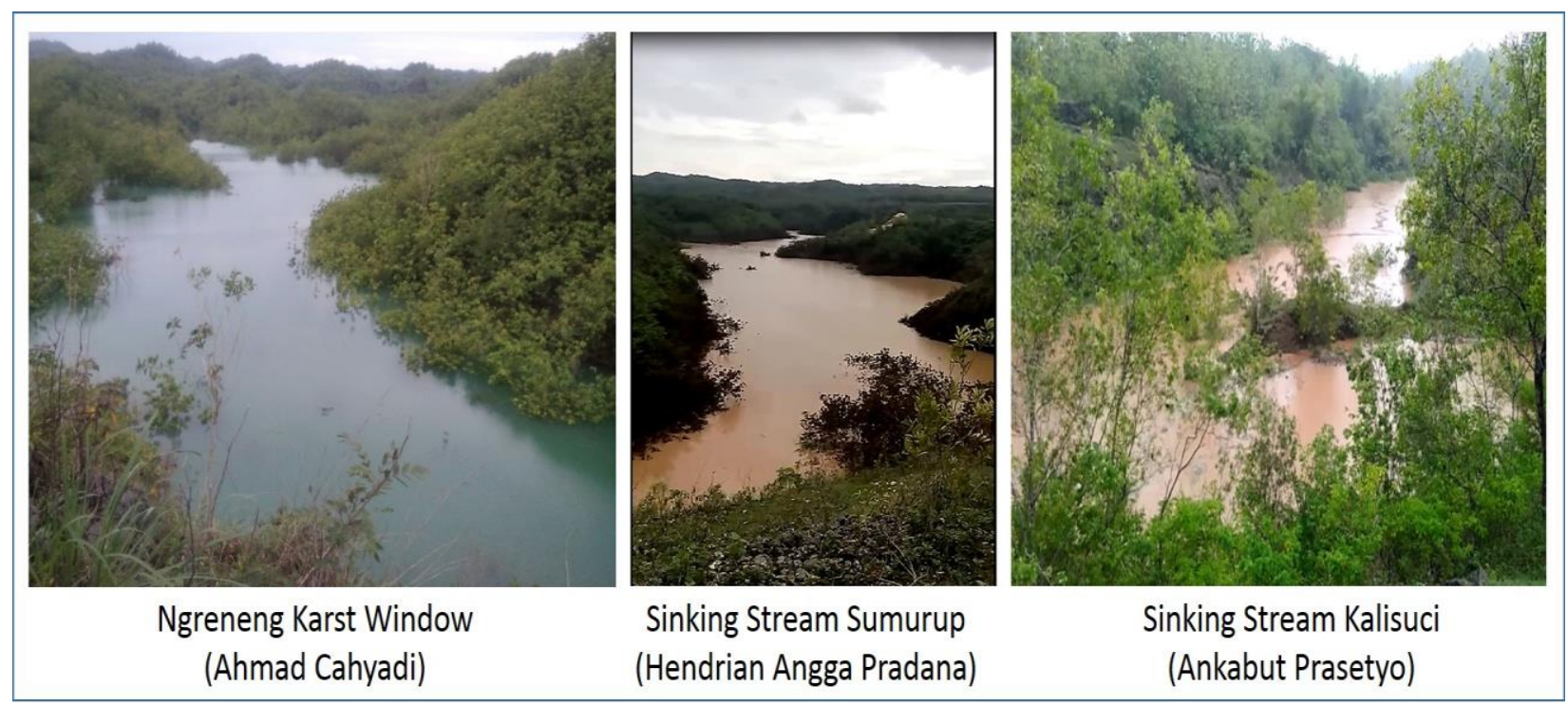

Gambar 8. Perbedaan Genangan di Sekitar Gua Ngreneng dengan Genangan di Sekitar Gua Sumurup dan Gua Kalisuci 
Paper ini merupakan versi preprint dari makalah berjudul "Groundwater flooding due to Tropical Cyclone Cempaka in Ngreneng Karst Window, Gunungsewu Karst Area, Indonesia”. Versi Bahasa Inggris dari paper ini kami presentasikan di "Joint International Conference on Hydro-Meteorological Disaster Mitigation Under Global Change" tanggal 29 November 2018 di Universitas Gadjah Mada Yogyakarta. Seminar ini diselenggarakan oleh Kementerian Lingkungan Hidup dan Kehutanan RI dan Klinik Lingkungan dan Mitigasi Bencana, Fakultas Geografi, Universitas Gadjah Mada

\section{CONCLUSION}

Hasil kajian menunjukkan bahwa pada saat terjadi banjir airtanah di Karst Window Ngreneng hujan berlangsung berturut-turut selama tiga hari. Penggenangan dimulai pada tanggal 28 November 2017 dengan curah hujan pada hari tersebut adalah $239 \mathrm{~mm} / \mathrm{hari}$ pada Stasiun Penelitian Gua Pindul dan 341 mm/hari di Stasiun ARR Tepus milik Badan Meteorologi, Klimatologi dan Geofisika. Daerah tangkapan dari Karst Window Ngreneng adalah DAS Bribin Hulu yang dipasok juga oleh aliran alogenik di luar Kawasan Karst Gunungsewu. Kejadian penggenangan terjadi selama 10 hari dengan luas genangan maksimum adalah 26,4 hektar. Banjir airtanah yang terjadi di Karst Window Ngreneng terjadi akibat aliran air yang melalui lorong konduit melebih kapasitas penyaluran, sehingga air pada lokasi kajian naik melalui karst window dan membentuk danau pada doline. Aliran diffuse yang memenuhi lorong lebih dahulu naik, sehingga air danau awalnya jernih. Setelah tiga hari air yang berasal dari saluran konduit mulai masuk dan menyebabkan air pada danau menjadi keruh.

\section{ACKNOWLEDGEMENT}

This research is part of a larger study entitled "Karakterisasi Resesi Hidrograf Aliran Karst untuk Penentuan Kapasitas Simpanan Air pada Beberapa Tipe Perkembangan Karst untuk Antisipasi Bencana Kekeringan", which receives funding from the Indonesian Ministry of Research, Technology and Higher Education under the scheme of Primary Higher Education Research Grant (Penelitian Dasar Unggulan Perguruan Tinggi-PDUPT) 2018.

\section{REFERENCES}

Adji, T.N. 2006. Peranan Geomorfologi dalam Kajian Kerentanan Air Bawah Tanah Karst. Gunungsewu: Indonesian Cave and Karst Journal, 2(1): 64-74.

Adji, T.N. 2010. Variasi Spasial-Temporal Hidrogeokimian dan Sifat Aliran untuk Karakterisasi Sistem Karst Dinamis di Sungai Bawah Tanah Bribin, Kabupaten Gunungkidul, Daerah Istimewa Yogyakarat. Disertation. Yogyakarta: Program Pascasarjana Fakultas Geografi Universitas Gadjah Mada. 
Paper ini merupakan versi preprint dari makalah berjudul "Groundwater flooding due to Tropical Cyclone Cempaka in Ngreneng Karst Window, Gunungsewu Karst Area, Indonesia”. Versi Bahasa Inggris dari paper ini kami presentasikan di "Joint International Conference on Hydro-Meteorological Disaster Mitigation Under Global Change" tanggal 29 November 2018 di Universitas Gadjah Mada Yogyakarta. Seminar ini diselenggarakan oleh Kementerian Lingkungan Hidup dan Kehutanan RI dan Klinik Lingkungan dan Mitigasi Bencana, Fakultas Geografi, Universitas Gadjah Mada

Adji, T.N. 2011. Kondisi Daerah Tangkapan Sungai Bawah Tanah Karst Gunungsewu dan Kemungkinan Dampak Lingkungannya Terhadap Sumberdaya Air (Hidrologis) Karena Aktivitas Manusia. in Sudarmadji; Haryono, E.; Adji, T.N.; Widyastuti, M.; Harini, R.; Nurjani, E.; Cahyadi, A.; dan Nugraha, H. (Eds). 2011. Ekologi Lingkungan Kawasan Karst Indonesia. Yogyakarta: Deepublish.

Cahyadi, A. 2016. Peran Telaga dalam Pemenuhan Kebutuhan Air di Kawasan Karst Gunungsewu Pasca Pembangunan Jaringan Air Bersih. Geomedia, 14(2): 23-33.

Cahyadi, A.; Riyanto, I.A.; Irshabdillah, M.R. and Firizqi, F. 2018. Inventarisasi dan Karakterisasi Sistem Sungai Alogenik di Kawasan Karst Gunungsewu Kabupaten Gunungkidul. Research Report. Yogyakarta: Faculty of Geography, Universitas Gadjah Mada.

Fatchurohman, H. and Cahyadi, A. 2011. Strategi Adaptasi Masyarakat Terhadap Bencana Kekeringan di Kawasan Karst Kecamatan Panggang, Gunungkidul. in Sudarmadji; Haryono, E.; Adji, T.N.; Widyastuti, M.; Harini, R.; Nurjani, E.; Cahyadi, A.; dan Nugraha, H. (Eds). 2011. Ekologi Lingkungan Kawasan Karst Indonesia. Yogyakarta: Deepublish.

Haryono, E. 2000. Some Properties of Epikarst Drainage System in Gunung Kidul Regency, Yogyakarta Special Province, Indonesia. The Indonesian Journal of Geography, 32: 7586.

Haryono, E; Adji, T.N. and Widyastuti, M. 2009. Problems of Telaga (Doline Pond) in Gunungsewu Karst, Java, Indonesia. in White, W.B. (Ed). 2009. Proceeding $15^{\text {th }}$ International Congress of Speleology, Vol. II. Texas: UIS.

Kusumayudha, S.B.; Setiawan, J.; Ciptahening, A.N. and Septianta, P.D.. 2015. Geomorphologic Model of Gunungsewu Karst, Gunung Kidul Regency, Yogyakarta Special Territory, Indonesia: The Role of Lithologic Variation and Geologic Structure. Journal of Geological Resource and Engineering, 1: 1-7.

Milanovic, P.T. 1981. Karst Hydrogeology. Colorado, USA: Water Resources Publications. 
Paper ini merupakan versi preprint dari makalah berjudul "Groundwater flooding due to Tropical Cyclone Cempaka in Ngreneng Karst Window, Gunungsewu Karst Area, Indonesia”. Versi Bahasa Inggris dari paper ini kami presentasikan di "Joint International Conference on Hydro-Meteorological Disaster Mitigation Under Global Change" tanggal 29 November 2018 di Universitas Gadjah Mada Yogyakarta. Seminar ini diselenggarakan oleh Kementerian Lingkungan Hidup dan Kehutanan RI dan Klinik Lingkungan dan Mitigasi Bencana, Fakultas Geografi, Universitas Gadjah Mada

Notosiswoyo, S. and Kusumayudha, S.B. 1998. Hydrogeology of The Gunungsewu Karstic Area, Central Java, Indonesia: A Conceptual Model. Proceeding of Ninth Regional Congress on Geology, Mineral and Energy Resources of South East Asia. Kuala Lumpur.

Sidauruk, P.; Prasetio, R.; Satrio. (2018). Hydraulic Interconections Study of Seropan-NgrenengBribin Undeground Rivers in Gunung Kidul Karst Area Using Tracing technique. International Journal of Water, 12(1): 39-53.

Sudarmadji; Suprayogi, S. dan Setiadi. 2012. Konservasi Mata Air Berbasis Masyarakat di Kabupaten Gunungkidul untuk Mengantisipasi Dampak Perubahan Iklim. Yogyakarta: Penerbit Sekolah Pascasarjana Universitas Gadjah Mada.

White, W.B. 1988. Geomorphology and Hydrology of Karst Terrains. New York: Oxford University Press.

Widyastuti, M.; Sudarmadji; Sutikno; and Hendrayana, H. 2012. Kerentanan Airtanah terhadap Pencemaran Daerah Imbuhan Ponor di Karst Gunung Sewu (Studi di Daerah Aliran Sungai Bawah Tanah Bribin. Jurnal Manusia dan Lingkungan, 19(2): 128-142. 